\title{
MODERN PROBLEMS OF MORBIDITY, CLINICAL AND EPIDEMIOLOGICAL FEATURES OF THE PSORIASIS COURSE IN PATIENTS OF THE KHARKIV REGION
}

\author{
A.A.Kotvitska, V.V.Carlo
}

\author{
National University of Pharmacy
}

Key words: psoriasis; statistical data; morbidity; prevalence; gender-age features

\begin{abstract}
The data on the current state and the major trends of the psoriasis morbidity in the Kharkiv region have been given in the article. It has been noted that psoriasis takes one of the leading places among the chronic diseases of the skin and it is not only medical, but also social and economic problem. A discrepancy between the official and the actual data on the prevalence of psoriasis in Ukraine has been proven. It has been determined that data about visits to medical preventive institutions do not reflect the actual number of patients. As a result of the structural analysis of patients by age of the dermatosis occurence it has been determined that almost $90 \%$ of the psoriasis patients took ill at the age less than 50 years, i.e. in the most able-bodied age, and 35\% of the patients became ill in their teens. It confirms the social and economic significance of the disease. The widespread forms of psoriasis, including Psoriasis vulgaris, and its the most serious complications psoriatic erythroderma, psoriasis arthropica, generalized pustular psoriasis have been determined. The main problems concerning the incidence of psoriasis in the Kharkiv region have been analyzed and generalized, as well as the main directions of improvement of medical and social care for patients have been identified.
\end{abstract}

Dsoriasis is one of the most common skin diseases, which peculiarity is the ability of recurrence. The share of psoriasis in the general structure of the skin morbidity is from 7 to $10 \%$, and among hospital patients with skin diseases it is $20-25 \%[2,4,6,7]$.

Psoriasis is a chronic systemic disease of the multifactorial nature, it is characterized by hyperproliferation of epidermal cells, disturbance of keratinization, inflammatory response in the dermis, changes in various organs and systems $[1,2,7]$.

Despite significant advances in the study of the nature of psoriasis, the presence of a large number of methods and treatments, this dermatosis takes one of the leading places among chronic skin diseases. That is why the study of the basic problems of morbidity, as well as clinical and epidemiological features of the psoriasis course becomes important both at the state and regional level.

The aim of our work was to study and analyze modern problems of morbidity and clinical and epidemiological features of the psoriasis course in patients in the Kharkiv region with further determination of the main directions for improving health and social care of patients.

\section{Materials and Methods}

In order to study clinical and epidemiological features of the psoriasis course we conducted a retrospective analysis of medical records of inpatients (767 in number) treated in the Kharkov regional sexual health clinic No. 1 in 2011-2013. The statistical, graphical and analytical research methods were used.

\section{Results and Discussion}

Noting that according to the data of the Centre for Medical Statistics of the Ministry of Public Health of Ukraine the number of inpatients with diseases of the skin and subcutaneous tissue in the Kharkiv region gradually decreases (from 752.8 patients per 100 thousand of the population in 2007 to 590 patients per 100 thousand of the population in 2012), the number of patients diagnosed with psoriasis in the Kharkov regional se-

xual health clinic No. 1 increases annually. Thus, 295 patients were treated there in 2011, in 2012 there were 335 patients, and only in the first quarter of 2013 the number of patients was 137 . These data suggest an increased rate by the nosology investigated and confirm the relevance of studying clinical and epidemiological features of psoriasis [5].

The analysis of gender patterns of patients with psoriasis in the dynamics of recent years indicates that men dominated in the total number of patients. Among the total number of cases the share of male patients that applied for help to the Kharkov regional sexual health clinic No. 1 gradually increased from $50.5 \%$ in 2011 to $64.2 \%$ in the first quarter of 2013 (Fig. 1).

The analysis has shown that most of the patients with psoriasis represent the economically active population - women and men in the age up to 60 years old. The gender and age structure of patients with psoriasis in the Kharkiv region is shown in Fig. 2.

Among the general number of patients $2.5 \%$ (19 patients) had the second group of disability, $3.1 \%$ (24 patients) - the third group of 
Patients, \%

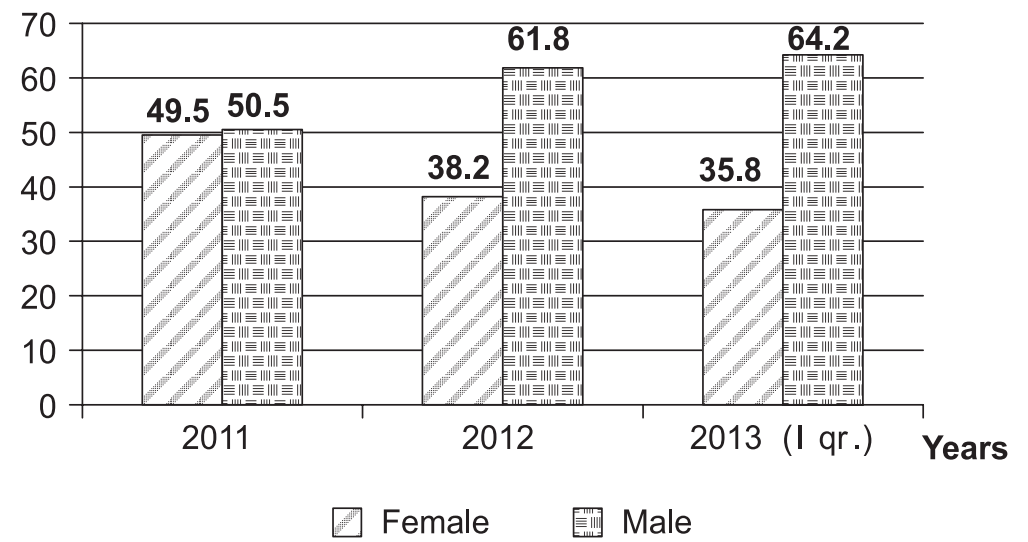

Fig. 1. The gender structure of patients with psoriasis

disability, $0.1 \%$ (1 patient) - the fourth group of disability. The given fact suggests that the incidence of psoriasis has not only direct losses to the state as costs for inpatient care considering that most patients seek help just to the state (budget) medical preventive institutions, but also indirect losses - government payments are increased on temporary disability, permanent partial or total disability; revenues to the Ministry of Revenue and Duties of Ukraine as a single social contribution, tax on the personal income and corporate profit enterprises associated with the reduced productivity are decreased.
As it has been found, the majority of patients appealed to doctors only at the stage of the severe course of dermatosis - the advanced stage of the disease was diagnosed in $98 \%$ of the patients.

As for forms of psoriasis, the most common is psoriasis vulgaris found in $71.4 \%$ of the patients, and among clinical varieties of it the maculopapular (69.7\%) and seborrheic $(1.6 \%)$ psoriasis is the most common, the drops-shaped psoriasis $(0.1 \%)$ is the least often. It should be mentioned that almost $26 \%$ of men and $21 \%$ of women were diagnosed with the most severe forms of psoriasis erythrodermia psoriatica, psoria- sis arthropathica, generalized pustular psoriasis (Tab. 1).

It has been proven that the most important socio-economic impact of severe psoriasis and psoriasis arthropathica is disability, which can begin at the early stage of the disease and become a lifelong problem. Because of disability, patients retire earlier or stop working at all. If the prognosis for the life of a patient with ordinary psoriasis turns out to be favourable, in the case of the most serious forms of dermatosis the disability and death are possible as a result of exhaustion and consequent development of severe infections $[3,4,7]$.

We have also analyzed the age at which the disease is detected for the first time. It has been found that about $30 \%$ of women became ill at the age of 11-20 years old, $26 \%$ - at the age of $21-35,9 \%$ at the age of 51-55, i.e. the incidence peaks account for ages when there are hormonal changes in women (setting of the menstrual period in women of the reproductive age, pregnancy or childbirth, menopause), which can be considered as initiating agents (predictors) of psoriasis. Concerning the male morbidity $60 \%$ of pati-

\section{Patients, \%}



Fig. 2. The gender and age structure of patients with psoriasis in the Kharkiv region 


\section{Analysis of forms of psoriasis diagnosed in patients of the Kharkov regional sexual health clinic No. 1}

\begin{tabular}{|c|c|c|c|c|c|c|c|c|c|c|}
\hline \multirow[b]{2}{*}{ Indicators } & \multicolumn{3}{|c|}{ Ordinary } & \multirow[b]{2}{*}{ 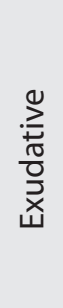 } & \multirow[b]{2}{*}{$\begin{array}{l}\stackrel{+}{\circ} \\
\frac{+}{1} \\
\frac{\varepsilon}{\sigma} \\
0\end{array}$} & \multirow[b]{2}{*}{ 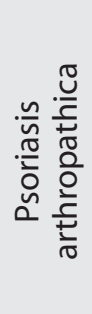 } & \multirow[b]{2}{*}{ 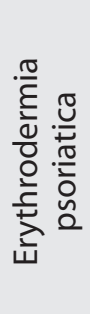 } & \multirow[b]{2}{*}{ 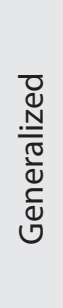 } & \multirow[b]{2}{*}{ 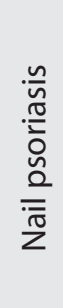 } & \multirow[b]{2}{*}{$\begin{array}{l}\bar{\pi} \\
\stackrel{0}{0}\end{array}$} \\
\hline & $\begin{array}{l}\frac{\bar{\pi}}{2} \\
\frac{0}{\pi} \\
\frac{0}{0} \\
\frac{0}{3} \\
\frac{0}{0} \\
\sum\end{array}$ & $\frac{\circ}{\stackrel{U}{\tilde{U}}}$ & 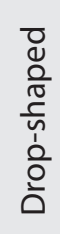 & & & & & & & \\
\hline \multicolumn{11}{|c|}{ Total number of patients } \\
\hline Number & 562 & 13 & 1 & 7 & 7 & 154 & 37 & 2 & 23 & 806 \\
\hline Share, $\%$ & 69.7 & 1.6 & 0.1 & 0.9 & 0.9 & 19.1 & 4.6 & 0.2 & 2.9 & \\
\hline \multicolumn{11}{|c|}{ Female } \\
\hline Number & 238 & 8 & - & 5 & 4 & 60 & 10 & 1 & 8 & 334 \\
\hline Share, \% & 71.2 & 2.4 & - & 1.5 & 1.2 & 18 & 3 & 0.3 & 2.4 & \\
\hline \multicolumn{11}{|c|}{ Male } \\
\hline Number & 324 & 5 & 1 & 2 & 3 & 94 & 27 & 1 & 15 & 472 \\
\hline Share, \% & 68.7 & 1.1 & 0.2 & 0.4 & 0.6 & 19.9 & 5.7 & 0.2 & 3.2 & \\
\hline
\end{tabular}

ents became ill for the first time at the age of 16-35 and the incidence peak in men account for the age of $16-20$ (20\% of cases) (Fig. 3) [1, 7].

According to the research results it has been found that nearly $90 \%$ of patients "get acquainted" with the disease under the age of 50 , i.e. in the most able-bodied age, and $35 \%$ of the patients became ill in their teens $140 \%$ of women and $30 \%$ of men). It con- firms the social significance of the disease.

Concerning duration of the psoriasis disease, only $10 \%$ of the patients in the sexual health clinic indicated that they suffered less than a year, $61 \%$ of patients suffered from dermatosis 6 years or more (Tab. 2). This fact is explained by the fact that psoriasis is a lifelong disease with frequent relapses; that is why patients who are ill for several months, and those suffer from it for decades have to seek the help of doctors equally often. Duration of the psoriasis disease patients in the Kharkov regional sexual health clinic No. 1 is shown in Table 2 .

According to Table 2 it has been determined that among the total number of inpatients medical records, in which duration of the patients' disease (726 medical records of 767) was indicated, $22.2 \%$ of the patients appealed to the me-

Patients, \%

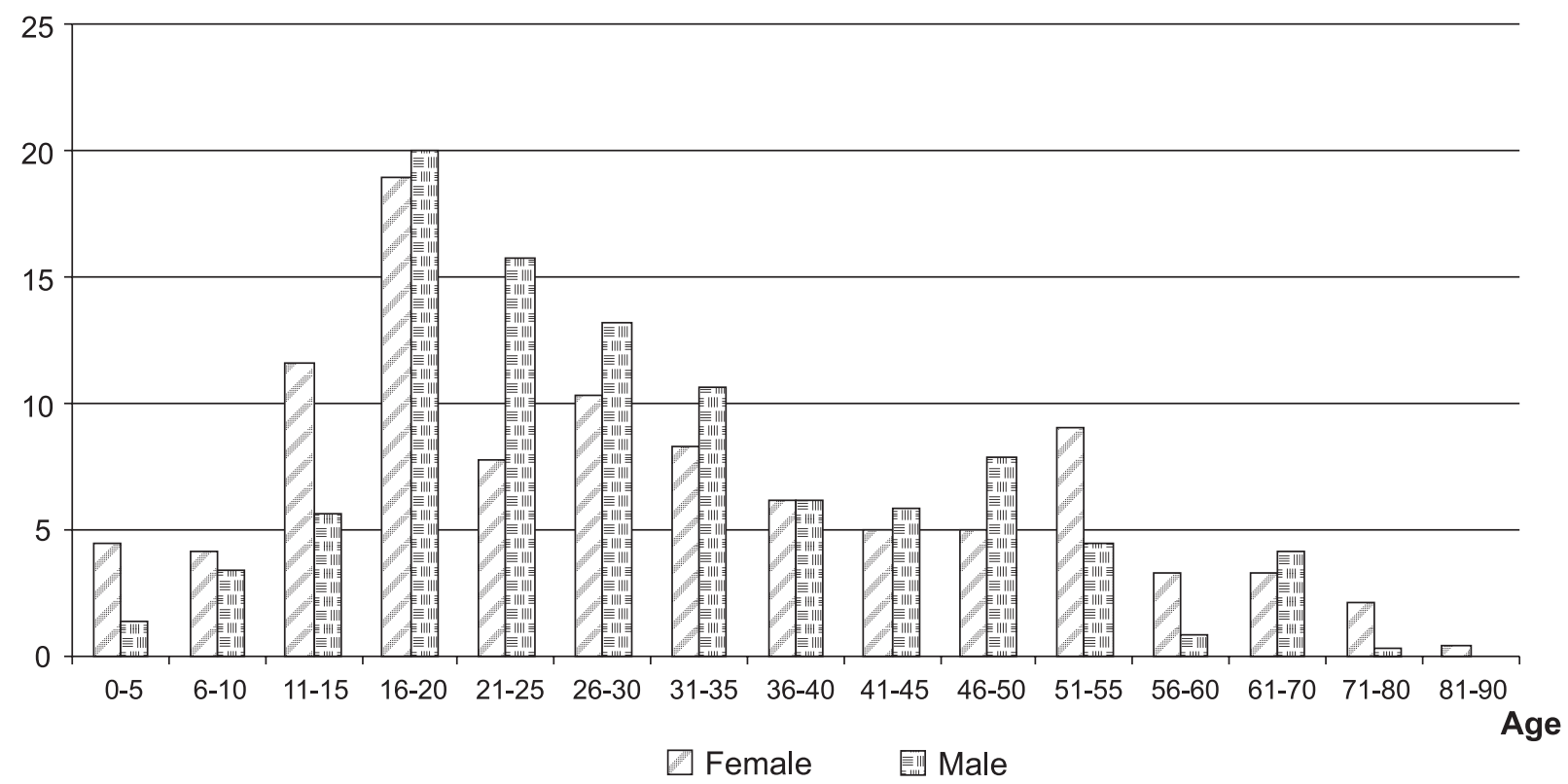

Fig. 3. The structural analysis of patients by age of the psoriasis occurence 
Table 2

\section{Duration of psoriasis disease in patients of the Kharkov regional sexual health clinic No. 1}

\begin{tabular}{|c|c|c|c|c|c|c|c|c|c|c|c|c|c|}
\hline \multirow{3}{*}{ No. } & \multirow{3}{*}{$\begin{array}{l}\text { Duration } \\
\text { of psoriasis }\end{array}$} & \multicolumn{6}{|c|}{$\begin{array}{l}\text { Patients who appealed to the medical } \\
\text { preventive institution }\end{array}$} & \multicolumn{6}{|c|}{ Patients who appealed for the first time } \\
\hline & & \multicolumn{2}{|c|}{ female } & \multicolumn{2}{|c|}{ male } & \multicolumn{2}{|c|}{ total number } & \multicolumn{2}{|c|}{ female } & \multicolumn{2}{|c|}{ male } & \multicolumn{2}{|c|}{ total number } \\
\hline & & $\begin{array}{l}\bar{\varpi} \\
\frac{0}{\xi} \\
\frac{\xi}{z}\end{array}$ & $\begin{array}{l}\stackrel{\circ}{\circ} \\
\frac{\dot{v}}{\bar{\sigma}} \\
\frac{\tilde{v}}{\sim}\end{array}$ & $\begin{array}{l}\frac{\bar{\Xi}}{\mathrm{J}} \\
\frac{\mathrm{E}}{\bar{z}}\end{array}$ & 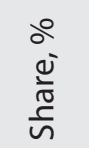 & $\begin{array}{l}\bar{\nu} \\
\frac{o}{\xi} \\
\frac{\xi}{z}\end{array}$ & 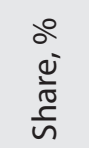 & $\frac{\bar{\varpi}}{\frac{\bar{\delta}}{\xi}}$ & 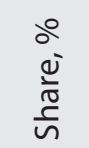 & 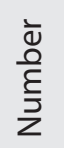 & 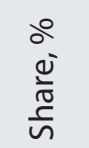 & 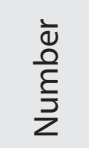 & 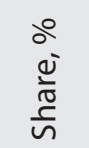 \\
\hline 1 & 1 week & 3 & 1 & 2 & 0.5 & 5 & 0.7 & 3 & 4 & 2 & 2.3 & 5 & 3.1 \\
\hline 2 & 2-3 weeks & 9 & 3 & 3 & 0.7 & 12 & 1.6 & 9 & 12.1 & 3 & 3.4 & 12 & 7.5 \\
\hline 3 & 1 month & 7 & 2.3 & 3 & 0.7 & 10 & 1 & 7 & & 3 & 3.4 & & 6.2 \\
\hline 4 & 1,5-2 months & 5 & 1.6 & 7 & 1.6 & 12 & 1 & 4 & & 1 & 8 & 11 & 6.8 \\
\hline 5 & 3-5 months & 10 & 3.3 & 7 & 1.6 & 17 & 2.3 & 7 & 9. & 5 & 5.8 & 12 & 7.5 \\
\hline 6 & 6-11 months & 9 & 3 & 9 & 2.1 & 18 & 2.5 & 4 & 5.4 & 5 & 5.8 & 9 & 5.6 \\
\hline 7 & 1 year & 15 & 5 & 27 & 6.4 & 42 & 5.8 & 8 & 10.8 & 10 & 11.5 & 18 & 11.2 \\
\hline 8 & $1,5-2$ years & 15 & 5 & 30 & 7.1 & 45 & 6.2 & 7 & 9.5 & 10 & 11.5 & 17 & 10.6 \\
\hline 9 & 3-5 years & 32 & 10.6 & 34 & 8 & 66 & 9.1 & 11 & 14.9 & 5 & 5.8 & 16 & 9.9 \\
\hline 10 & 6-10 years & 39 & 12.9 & 76 & 17.9 & 115 & 15.8 & 4 & 5.4 & 14 & 16.1 & 18 & 11.2 \\
\hline 11 & $11-15$ years & 16 & 5.3 & 35 & 8.3 & 51 & 7 & & & 1 & 1.2 & 1 & 0.6 \\
\hline 12 & $16-20$ years & 23 & 7.6 & 34 & 8 & 57 & 7.9 & 1 & 1.3 & 2 & 2. & 3 & 1.9 \\
\hline 13 & $21-30$ years & 20 & 6.6 & 36 & 8.5 & 56 & 7.7 & & & 2 & 2.3 & 2 & 1.2 \\
\hline 14 & $31-40$ years & 19 & 6.3 & 12 & 2.8 & 31 & 4.3 & & & & & & \\
\hline 15 & $>40$ years & 10 & 3.3 & 13 & 3.1 & 23 & 3.2 & & & & & & \\
\hline 16 & few years & 22 & 7.3 & 32 & 7.6 & 54 & 7.4 & 7 & 9.5 & 15 & 17.2 & 22 & 13.6 \\
\hline 17 & many years & 48 & 15.9 & 64 & 15.1 & 112 & 15.4 & 2 & 2.7 & 3 & 3.4 & 5 & 3.1 \\
\hline & TOTAL: & 302 & & 424 & & 726 & & 74 & 24.5 & 87 & 20.5 & 161 & 22.2 \\
\hline
\end{tabular}

dical preventive institution seeking medical help for the first time. Of particular note is the fact that only 59 patients $(36.7 \%)$ suffered from dermatosis less than 1 year (among them only 17 (10.6\%) the first manifestations of psoriasis lasted 1 month). Most patients were not treated for years, or treated themselves, including 35 patients (21.8\%) sought medical help for the first time after suffering 1-2 years, 34 patients $(21.1 \%)$ - after 3-10 years of the disease, 6 patients (37\%) - after $11-30$ years of the disease, 22 patients $(13.6 \%)$ indicated that they were ill for several years, and 5 patients (3.1\%) suffered for many years.

It should be noted that some patients are sometimes not even aware of the disease (especially with mild psoriasis) and do not treat, or prefer alternative medicine (healers, traditional healers) and representatives of the network marketing. However, it is known that in the case of late initiation of therapy the disease can lead to development of severe forms of psoriasis and the patient's disability [7].

Considering that more than $40 \%$ of patients seek medical attention for the first time after 3-30 years of living with psoriasis the question about the prevalence of psoriasis in Ukraine remains controversial since according to the official statistics of the Ministry of Public Health of Ukraine in 2011 there were more than 102,000 patients representing only $0.21 \%$ of the total population. It is worth noting that the official statistics also contradicts the data of the International Federation of Psoriasis Associations because the prevalence of psoriasis in the world is about 2.5-3\% of the general population, and if we extrapolate these statistics on Ukraine, the real number of patients with psoriasis in our count- ry is more than one million people [7].

The fact that in Ukraine patients try to be self-treated seeking medical help only after prolonged exacerbation and / or at the severe stage of the disease indicates that about $50 \%$ of the patients visit the medical institution with the period of dermatosis exacerbation from 1 month to 1 year, and 6 patients $(1.5 \%)$ indicated even a longer period of exacerbation over 2 years (Tab. 3 ).

Thus, taking into accout the clinical and epidemiological features of psoriasis in patients of the Kharkov regional sexual health clinic No. 1 it can be argued that the significance of the problem of psoriasis, despite the large number of medicines and treatments, is conditioned by the following components:

- the absence of representative statistics and the national registry of patients with psoria- 


\section{Duration of exacerbation of psoriasis in patiens of the Kharkov regional sexual health clinic No. 1}

\begin{tabular}{|c|l|c|c|c|c|c|c|}
\hline \multirow{2}{*}{ No. } & \multirow{2}{*}{ Duration of exacerbation } & \multicolumn{2}{|c|}{ Female } & \multicolumn{2}{c|}{ Male } & \multicolumn{2}{c|}{ Total number } \\
\cline { 3 - 9 } & & Number & Share, $\%$ & Number & Share, \% & Number & Share, \% \\
\hline 1 & Few days & 6 & 3.4 & 4 & 1.7 & 10 & 2.5 \\
\hline 2 & 1 week & 24 & 13.6 & 32 & 13.9 & 56 & 13.8 \\
\hline 3 & 2 weeks & 45 & 25.4 & 58 & 25.2 & 103 & 25.3 \\
\hline 4 & 3 weeks & 12 & 6.8 & 10 & 4.3 & 22 & 5.4 \\
\hline 5 & 1 month & 47 & 26.5 & 59 & 25.7 & 106 & 26 \\
\hline 6 & $1.5-2$ months & 26 & 14.7 & 38 & 16.5 & 64 & 15.7 \\
\hline 7 & $3-5$ months & 11 & 6.2 & 20 & 8.7 & 31 & 7.6 \\
\hline 8 & 6 months & 2 & 1.1 & 2 & 2.2 & 5 & 1.2 \\
\hline 9 & 1 years & 4 & 2.3 & 2 & 0.9 & 4 & 1 \\
\hline 10 & $>2$ years without remisson & 177 & 43.5 & 230 & 56.5 & 407 & 1.5 \\
\hline & TOTAL: & & & 5 & & 6 \\
\hline
\end{tabular}

sis (currently more than 1 million people suffer from psoriasis in Ukraine, although, according to official statistics, they are less than 100 thousand people);

- the low awareness of patients about the disease;

- a rapid development of irreversible dysfunctions of organs and body systems caused by both the disease and the therapy used;

- the low level of awarenessraising activities among the population, in particular with the emphasis on the risk of disability in the case of the absence of timely and qualified treatment;

- the low level of awareness among patients about modern methods of treatment that can provide the quality of life of patients with psoriasis.

The main areas of improvement of medical and social care for patients with psoriasis are:

- creation of the national registry of patients with psoriasis;

- awareness-raising activities among the population, in particular with the emphasis on the risk of disability in the case of the absence of adequate and timely treatment;

- conducting educational work among the population to en- sure understanding of the disease peculiarities and eliminate the initiating agents;

- improvement of the system of early detection and timely diagnosis by increasing the efficiency of preventive and follow-up observation;

- introduction of standards of treatmentfor patients with psoriasis based on the latest advances and evidence-based and practical medicine;

- improvement of the material and technical base of specialized dermatological departments due to additional funding from the state and local budgets.

\section{CONCLUSIONS}

1. According to the results of analysis it has been found that despite the considerable number of methods and treatments psoriasis occupies one of the leading places among the chronic skin diseases, and at the same time with decrease in the number of hospitalized patients with diseases of the skin and subcutaneous tissue in the Kharkov region (from 752.8 patients per 100 thousand people in 2007 to 590 patients per 100 thousand people in 2012) the number of the patients diagnosed with psoriasis in the Kharkov regional sexual health clinic No. 1 increases annually.
2. As a result of the gender and age analysis it has been determined that in the total number of patients men are $64.1 \%$ of the patients, women are $36.9 \%$, among them about $90 \%$ of the patients are economically active part of the population under the age of 60 .

3 . According to the retrospective analysis of medical records of inpatients treated in the Kharkov regional sexual health clinic No. 1 in 2011-2013, psoriasis vulgaris (found in $71.4 \%$ of patients) is the most common diagnosis. The most severe forms of psoriasis include psoriatic erythroderma, psoriasis arthropica, generalized pustular psoriasis diagnosed in $26 \%$ of men and $21 \%$ of women.

4. The results of the structural analysis of the patients by the age of the psoriasis occurence suggest that almost $90 \%$ of the patients became ill under the age of 50 , i.e. in the most able-bodied age, and $35 \%$ of the patients became ill in their teens. It confirms the social significance of the disease.

5. It has been proven that the prevalence of psoriasis in Ukraine according to the data concerning appeal for help to the medical preventive institutions does not reflect the actual number of patients, whereas $40 \%$ of the patients visiting the medical insti- 
tution for the first time indicated their disease duration from 3 to 30 years. A significant number of patients after diagnosis tries to be self-treated seeking medical help only after prolonged exacerbation (50\% of the patients indicated a period of exacerbation from 1 month to 1 year).

6. The main problems concerning the incidence of psoriasis in the Kharkiv region have been analyzed and generalized, as well as the main directions of improvement of medical and social care for patients have been identified. Among them the most important directions are creation of the national registry of patients with psoriasis; awareness-raising activities among the population with the emphasis on the risk of disabi- lity in the case of the absence of adequate and timely treatment; improvement of the system of early detection and timely diagnosis by increasing the efficiency of preventive and follow-up observation; introduction of standards of treatment for patients with psoriasis based on the latest advances and evidence-based and practical medicine.

\title{
REFERENCES
}

1. Болотная Л.A. // ARS medica. - 2011. - №15 (51). - C. 113-114.

2. Котвіцька А.А., Карло В.В. // Запорізький мед. журн. - 2013. - №3. - С. 38-42.

3. Chandran V., Raychaudhuri S.P. // J. of Autoimmunity. - 2010. - Vol. 34. - P. 314-321.

4. Parisi R., Symmons D.P., Griffiths C.E., Ashcroft D.M. // J. of Investigative Dermatol. - 2013. - №133 (2). P. 377-385.

5. http://medstat.gov.ua/ukr/main.html

6. https://www.psoriasis.org/learn_statistics

7. www.psoriasis.in.ua

\section{СУЧАСНІ ПРОБЛЕМИ ЗАХВОРЮВАНОСТІ ТА КЛІНІКО-ЕПІДЕМІОЛОГІЧНІ ОСОБЛИВОСТІ ПЕРЕБІГУ ПСОРІАЗУ У ХВОРИХ ХАРКІВСЬКОГО РЕГІОНУ}

А.А.Котвіцька, В.В.Карло

Національний фармацевтичний університет

Ключові слова: псоріаз; статистичні дані; поширеність; захворюваність; гендерно-вікові особливості

Наведені дані щодо сучасного стану та основних тенденцій захворюваності на псоріаз у Харківському регіоні $і$ відзначено, що псоріаз посідає одне з лідируючих місць серед хронічних захворювань шкіри іє не лише медичною, а й соціально-економічною проблемою. Доведена невідповідність офіційних та фактичних даних щодо поширеності псоріазу в Україні та зауважено, що дані звернень до лікувально-профілактичних закладів не відображають реальної кількості хворих. За результатами структурного аналізу хворих за віком, коли з'явились ознаки дерматозу, встановлено, що майже 90\% пацієнтів захворіли у віці до 50 років, тобто у найбільш працездатному віці, а у 35\% хворих псоріаз розпочався у віці до 20 років, що підтверджує соціальну та економічну значущість захворювання. Визначені найбільш розповсюджені форми псоріазу, зокрема псоріаз звичайний та найбільш важкі його форми - псоріатична еритродермія, артропатичний псоріаз, генералізований пустульозний псоріаз. Проаналізовані та узагальнені основні проблеми захворюваності на псоріаз у Харківському регіоні, а також визначені основні напрямки удосконалення медико-соціальної допомоги хворим.

\section{СОВРЕМЕННЫЕ ПРОБЛЕМЫ ЗАБОЛЕВАЕМОСТИ И КЛИНИКО-ЭПИДЕМИОЛОГИЧЕСКИЕ ОСОБЕННОСТИ ТЕЧЕНИЯ ПСОРИАЗА У БОЛЬНЫХ ХАРЬКОВСКОГО РЕГИОНА}

\section{А.А. Котвицкая, В.В. Карло}

\section{Национальный фармацевтический университет}

Ключевые слова: псориаз; статистические данные; распространенность; заболеваемость; гендерно-возрастные особенности

\begin{abstract}
Приведены данные о современном состоянии и основных тенденциях заболеваемости псориазом в Харьковском регионе и отмечено, что псориаз занимает одно из лидирующих мест среди хронических заболеваний кожи и является не только медицинской, но и социально-экономической проблемой. Доказано несоответствие официальных и фактических данных о распространенности псориаза в Украине и установлено, что данные обращений в лечебно-профилактические учреждения не отражают реального количества больных. В результате структурного анализа больных по возрасту появления дерматоза установлено, что почти $90 \%$ пациентов заболели в возрасте до 50 лет, то есть в наиболее трудоспособном возрасте, а у 35\% больных псориаз начался в возрасте до 20 лет, что подтверждает социальную и экономическую значимость заболевания. Определены наиболее распространенные формы псориаза, в том числе псориаз обычный и наиболее тяжелые его формы - псориатическая эритродермия, артропатический псориаз, генерализованный пустулезный псориаз. Проанализированы и обобщены основные проблемы заболеваемости псориазом в Харьковском регионе, а также определены основные направления совершенствования медико-социальной помощи больным.
\end{abstract}

